\title{
AUTOMATION OF SECURITIES MARKETS AND THE EUROPEAN COMMUNITY'S PROPOSED INVESTMENT SERVICES DIRECTIVE
}

\author{
Norman S. Poser* \\ I \\ INTRODUCTION
}

This article focuses on one aspect of the European Community's ("EC's") proposed Investment Services Directive ("ISD"): the potential impact of the ISD on the automation of the European securities markets. ' The ISD will not only create a single European market for investment services, but will also play a part in determining how the European markets will operate, who will be permitted to participate in them, and how technology will affect their operation. Monitoring technology developments is particularly relevant as computers are rapidly making traditional methods of trading securities and of clearing and settling transactions obsolete.

Once the ISD comes into effect, it will reduce the regulatory burden on a national of any member state of the European Community that establishes an investment business and provides investment services throughout the Community. The ISD will give an investment firm access to membership in the stock exchanges and other organized securities markets located throughout the EC. Thus, an investment firm domiciled in one member state ("home state") may set up a branch or subsidiary in another state ("host state"), and will have the right to become a member of a stock exchange in the host state. Alternatively, the investment firm may acquire an existing member firm in the host state. ${ }^{2}$

Furthermore, a recent draft of the proposed directive contemplates crossborder access, through remote electronic terminals, to membership in stock exchanges or other markets that have no trading floor, but instead operate by means of computerized trading systems. If an investment firm in one member state seeks to become a member of such an electronic exchange in another

Copyright $\odot 1992$ by Law and Contemporary Problems

* Professor of Law, Brooklyn Law School.

I wish to thank Ruben Lee, of Nuffield College, Oxford University, for his helpful comments on this article. He bears no responsibility for any errors, however. I also wish to thank Brian Griffin, my research assistant.

1. See E. Waide Warner, "Mutual Recognition" and Cross-Border Financial Services in the European Community, 55 L \& Contemp Probs 7 (Autumn 1992).

2. EC Investment Services Directive, A Consultative Document art 13(2) (Department for Enterprise, May 28, 1990) (issued by the Council President) ("Investment Services Directive"). 
member siate, the home state must allow the stock exchange or market in the host state to install "appropriate facilities" (for example, computer terminals, software, and communications) within the firm's home state, to enable the firm to trade electronically across borders. ${ }^{3}$

As of the end of 1991, however, the ISD had not yet been approved by the EC Commission, and it now seems unlikely that the directive will be adopted by the EC Council of Ministers and implemented by the national legislation of each member state before the scheduled deadline of January 1, 1993.4 On that date, the Second Banking Directive ("SBD"), which the Council of Ministers adopted in 1989 , will take effect. ${ }^{5}$

As Waide Warner accurately points out in his contribution to this symposium, if the SBD takes effect before the ISD does, non-bank investment firms will suffer a competitive disadvantage. ${ }^{6}$ Under this scenario, a bank domiciled in any EC member state will be free to provide investment services throughout the Community, whereas a non-bank investment firm will not have that privilege, and will continue to be restricted by national legislation.

The principal reason for the delay in gaining EC approval for the ISD has been a fundamental disagreement among the EC member states as to how the EC securities markets should be structured. Two of the principal areas of disagreement are: (1) the extent to which securities trading should be confined to established stock exchanges, and (2) the timing and content of the reporting of transactions. ${ }^{7}$ These disagreements represent a more general tension between two important, but not necessarily consistent, values: (1) achieving cooperation among the various trading markets of Europe to facilitate cross-border trading, and (2) maximizing competition among these markets. The disagreements can be understood only against the background of the European securities markets' deregulation over the past five years.

3. Id at art 13(3); Department of Trade and Industry (UK), EC Investment Services Directive, A Consultative Document 23 If 87 (July 1990).

4. Andrew Hill, EC push for standard securities rules, Fin Times $4 \mathrm{col} 1$ (Dec 16, 1991); Talks on EC share trading rules delayed, Fin Times 20 col 5 (Mar 13, 1992).

Agreement was reached on the ISD in July 1992. Amended Proposal for a Council Directive on Investment Services in the Securities Field, SN 3158/92 (LEF) July 3, 1992 ("ISD (1992 Draft)"). The 1992 agreement on the ISD provides: (1) that the government of each member state will have the right to require that all trading take place on a "regulated market," a term that is defined as a market that functions regularly and is subject to national requirements relating to its operations, access to the market, the admission of securities to listing, and disclosure of transactions; and (2), on the question of disclosure or transaction, that each member state must require minimum disclosure for each security, according to a rather complex set of rules that permit limited delays of disclosure. ISD (1992 draft), arts 1 (11a), 12, 13, and 16b.

5. Second Council Directive on the Coordination of Laws, Regulations and Administrative Provisions Relating to the Taking Up and Pursuit of the Business of Credit Institutions Amending Directive 77/780; Council Directive 89/646, 1989 OJ (L. 386).

6. See Warner, $55 \mathrm{~L} \&$ Contemp Probs at 17 (cited in note 1).

7. Two other areas of disagreement, which are not discussed in this article, are whether banks should be permitted to become members of stock exchanges and what the capital-adequacy requirements applicable to investment firms should be. 


\section{Deregulation of the European Securities Markets}

In 1986, the deregulation of the London Stock Exchange ("LSE"), known as "Big Bang," revolutionized the U.K. securities markets. Big Bang consisted of four related initiatives: (1) it replaced the fixed commission rates that brokers charged their customers with competitive rates; (2) it opened exchange membership to foreign firms and banks; (3) it replaced the LSE's traditional open-outcry trading system with a computerized system in which competitive market-makers showed their quotations (for example, offers to buy and sell securities) on desktop screens that were available to any person who wished to subscribe; and (4) it abolished the "single capacity" restrictions, which required every investment firm to choose whether it wished to act as an agent for customers or as a "jobber" (dealer) for its own account, thus permitting all firms, including market makers, to act in the dual capacity of broker and dealer.

A related initiative is the contemplated replacement of the United Kingdom's inefficient two-week clearing-and-settlement system with an electronic three-day system known as "Taurus," which would eliminate stock certificates and paperwork incidental to share transfers. Owing to a host of technical and legal problems, however, Taurus has been repeatedly delayed and is not expected to begin operation until $1994 .^{8}$

Big Bang greatly reduced investors' transaction costs on the LSE, particularly in executing the large transactions of financial institutions. ${ }^{9}$ London thus became a far more competitive place for financial institutions to buy and sell securities. Between 1986 and 1988, the average commission rate on institutional transactions in U.K. equities fell from 0.4 percent to slightly under 0.25 percent of the value of the transaction, before stabilizing at the latter level. The level of commissions paid on transactions in foreign equities was somewhat lower than on U.K. equities, presumably because the average size of these foreign transactions was greater. ${ }^{10}$ Furthermore, many institutional transactions were done on a "net" basis." I

Competition among market makers also reduced transaction costs by narrowing the market "touch" (the spread between the highest bid to buy and the lowest offer to sell for a particular security), although market touches widened considerably as a result of the drying up of trading volume following the 1987 market crash. ${ }^{12}$ The U.K. government also did its part in reducing

8. Richard Waters, Parliament approves Taurus changes, Fin. Times, Feb 12, 1992, at 19 col. 1; Goodbye to all that, The Economist, July 25, 1992, at 78.

9. The same was not true for individual investors, whose transaction costs rose after Big Bang

10. London Stock Exchange, Stock Exchange Quarterly 21, 23 (July-Sept, 1991).

11. Id at 19-24. The term "net" means that the broker acted as principal, buying from an institution or selling to an institution, as opposed to acting as an agent for the institution. The broker thus received no commission.

12. Bank of England Quarterly Bulletin, Change in the Stock Exchange and regulation of the City 54, 58-59 (Burrup Lıd, Feb 1987); International Stock Exchange, Quality of Markets Quarterly Review 10-12 (Oct-Dec 1990). 
transaction costs by cutting the stamp tax on securities transactions from one percent to 0.5 percent. ${ }^{13}$ These developments led to a substantial gain in the competitiveness of the LSE. ${ }^{14}$ Even though transaction costs on the LSE rose after the 1987 market crash, London retained its relative advantage over other European markets.

The improved efficiency of the London market attracted a substantial portion of the market activity in the equity securities of large continental European companies. The LSE has become by far the largest market in the world for the trading of foreign equity securities, accounting for two-thirds of the worldwide total of reported equity trading outside the security's country of origin. In 1990, the shares of 613 foreign companies were traded on the LSE. Trading volume of foreign equities in London totaled $£ 147.8$ billion, twenty-two times that of its closest European competitor, the Federation of German Stock Exchanges. ${ }^{15}$ In the first quarter of 1991, the LSE accounted for $\mathbf{5 2 . 9}$ percent of the total reported trading volume in Dutch stocks traded in the Netherlands; the corresponding figures were 45.0 percent for Sweden, 35.5 percent for Switzerland, 29.5 percent for France, 24.7 percent for Italy, and 18.4 percent for Spain. ${ }^{16}$

In order to reverse the erosion of their domestic securities business caused by competition from London, the other European countries hastened to reduce investors' transaction costs by deregulating their own markets. ${ }^{17}$ France replaced fixed brokerage commissions with negotiable commissions in $1989,{ }^{18}$ the Netherlands followed in $1990,{ }^{19}$ Switzerland in $1991,{ }^{20}$ and Spain plans to do so in 1992.21 France opened up stock exchange membership, or ownership of members, to banks and other financial firms in $1988,{ }^{22}$ Spain in $1989,{ }^{23}$ Sweden (partially) in $1990,{ }^{24}$ and Italy in $1991 .{ }^{25}$ The Netherlands and Sweden abolished stock transfer taxes in 1990;26 Germany did the same in 1991.27 (In Switzerland, however, a voters' referendum in 1991 rejected

13. The U.K. government has stated that it will repeal the stamp tax altogether when the Taurus settlement system begins operations. The end of privilege, The Economist 86, 90 (Dec 14, 1991).

14. See Marco Pagano and Ailsa Roell, Stock Markets, Economic Policy 67 (Apr 1990).

15. Bank of England Quarterly Bulletin, Global Equity Tumover: market comparisons 246-49 (Burrups Ltd, May 1991). The LSE's nearest competitor worldwide in the trading of foreign stocks is NASDAQ, the U.S. computerized over-the-counter market, which does about one-tenth of the London volume in foreign stocks.

16. Id.

17. I surveyed France, Germany, Italy, the Netherlands, and Spain (all of which are EC member states), and Sweden and Switzerland (which are not EC member states).

18. Norman S. Poser, International Securities Regulation: London's "Big Bang" and the European Securities Markets 834 (Little Brown, 1990).

19. Id at 120 (Supp 1991).

20. Id at 108 .

21. Id at 127 .

22. Id at 383-84.

23. Id at 436-37.

24. Id at $430-31$.

25. Id at 115-16.

26. Id at 429 and 120 (Supp 1991).

27. Id at 103-04. 
abolition of the country's three percent stock transfer tax. ${ }^{28}$ ) Despite these deregulatory steps, however, the continental European countries do not appear yet to have recaptured a substantial amount of the foreign equity trading that they lost to London. ${ }^{29}$

By the end of 1991, the process of deregulation of the world's securities markets, which began in the United States on "Mayday" (May 1, 1975) with the abolition of fixed commission rates by the Securities and Exchange Commission, ${ }^{30}$ and gained momentum in 1986 with the United Kingdom's Big Bang, has now spread to the most important securities markets on the European continent.

\section{Automation of the European Securities Markets}

An important part of the movement to make the markets more efficient is the disappearance of trading floors, where dealers and brokers executed transactions by systems of open outcry, and the replacement of these outcry systems with screen-based electronic trading systems, where brokers and dealers trade with each other from their own offices through a central computer. Systems for computerized trading (automated execution of transactions), or for computerized dissemination of market information (in some cases designed to lead to computerized trading), were introduced on a full or partial basis in the United Kingdom and France in 1986, ${ }^{31}$ in Sweden in $1988,{ }^{32}$ in Spain in $1989,{ }^{33}$ in the Netherlands in $1990,{ }^{34}$ and in Germany and Italy in 1991.35 Computerized trading is scheduled to begin in Switzerland in $1992 .{ }^{36}$

Computerized trading has many advantages over traditional methods of trading. It tends to improve the efficiency of the markets by reducing transaction costs, by expediting the execution of orders to buy and sell securities, by expediting the reporting of executions to investors, and by accommodating a greater number of participants than is possible in a traditional trading system. Computerized trading also tends to promote competition, improve the transparency of markets, and increase the opportunities for best execution. ${ }^{37}$ Furthermore, computerized trading

28. Id at 109.

29. Bank of England Quarterly Bulletin, Global Equity Turnover at 248 (cited in note 15).

30. Exchange Act Rel No 11,203, 40 Fed Reg 7394 (Feb 20, 1975) (adopting rule 19b-3, 17 CFR 240.19b-3) (removed in 53 Fed Reg 41206, (1988)).

31. Poser, International Securities Regulation at 43, 384 (cited in note 18).

32. Id at 431 .

33. Id at 437-38.

34. Id at 423 and 120 (Supp 1991).

35. Id at 105-06 (Supp 1991); Milan brings in screen-based dealing as bourses fall, Fin Times 44 col 3 (Nov 26, 1991).

36. Poser, International Securities Regulation at 110 (cited in note 18).

37. William H. Heyman, Response to Letter from Chairman Markey concerning Computerized Trading Systems 11 (July 3, 1991) (memorandum from William H. Heyman, Director, Division of Market Regulation, to Richard C. Breeden, Chairman, SEC) ("Computerized Trading Systems"). (The 
improves the fairness of the markets by making it more likely that all investors will be treated equally, and by increasing the ability of regulators to monitor the markets effectively. A computerized trading system can also be tied into a computerized clearing and settlement system, eliminating much of the paperwork done by brokerage firms and clearing houses. This system reduces the likelihood of errors and hastens the processing of transactions.

Finally, because geographic distances pose no obstacle to screen-based trading, an automated trading system readily lends itself to the creation of an international securities market. ${ }^{38}$ For the same reason, automated trading also enables regional markets within a particular country to be consolidated into a national system; this is happening, for example, in Germany, where the "Ibis" electronic screen-based "matched-order" trading system gives members of regional exchanges access to the larger Frankfurt market for the first time. ${ }^{39}$

On the negative side, an automated system requires a substantial investment of capital, which may be recoverable only after a lengthy period if the level of trading activity is low, as it was in the years 1988-90. In addition, because even the best system is subject to potential breakdown, backup systems are required, adding to the expense of operation. Also, despite the regulators' capacity to monitor the system, unscrupulous persons may be able to use it to accomplish sophisticated manipulations.

Two general points may be made about the establishment of computerized trading systems in the European securities markets. First, the dispute among EC member states, which delayed the adoption of the ISD, was based largely on differences of opinion as to how the modernization of the EC securities markets should proceed. Some individual member states have established different types of computerized trading systems. Essentially, the dispute was between the United Kingdom, which has a "quote-driven" trading system of competing market makers, in which investors respond to prices quoted by market makers, and France, which has an "order-driven" system, which matches customers' orders that have been routed to a central facility. ${ }^{40}$

Second, computerization of the European markets is likely to have important long-term consequences for the U.S. markets. Although the United States began the process of global deregulation in 1975 by abolishing fixed commission rates and opening stock exchange membership to all qualified broker-dealers, and although the enormous U.S. equity markets appear to

memorandum is an attachment to a letter, dated July 11, 1991, from Chairman Breeden to Congressman Edward J. Markey, Chairman, Subcommittee on Telecommunications and Finance, House of Representatives Committee on Energy and Commerce.) See note 46 and accompanying text for discussion of best execution duty by agents.

38. Investment Services Directive art 13(3) (cited in note 2).

39. Poser, International Securities Regulation at 106 (cited in note 18); Katherine Campbell, German exchanges agree to Ibis system, Fin Times $19 \mathrm{col} 1$ (Sept 9, 1991). Automation may also help lead to the demise of regional stock exchanges. In October 1992, the eight German exchanges announced that they would merge to form a single German exchange, dominated by the Frankfurt Stock Exchange. David Waller, German bourses combine to take on Europe, Fin Times 17 (Oct 8, 1992).

40. Last Orders?, The Economist 91 (Mar 14, 1992). 
have the most to gain from the cost-cutting effects of automation, the U.S. stock exchanges-the NYSE in particular-did not change their trading methods when they were deregulated. Trading on the NYSE is done through the specialist system, as it has been since the late nineteenth century. Competition from more efficient markets, however, is already pressuring the U.S. stock exchanges to make greater use of computer technology. The London and Paris systems provide contrasts to the U.S. system and to each other.

\section{A. SEAQ: The Quote-Driven System of the London Stock Exchange}

The LSE's Stock Exchange Automated Quotations (“SEAQ") trading system began operation on the day of Big Bang, October 27, 1986. Adapted from NASDAQ, the automated trading system that has been used in the U.S. over-the-counter market since 1971, SEAQ is a system of market makers who publish competing bid-and-asked quotations. ${ }^{41}$ A firm authorized to conduct investment business in the United Kingdom may apply to the LSE to be registered as a market maker in a particular security. Once registered, a market maker is obliged to maintain "firm" continuous two-way quotations in that security during the period that the LSE is open for business. The "size" (number of shares) of the bids and offers that the market maker is required to quote for a given security depends on the security's normal market size, which is based on its public trading volume during the preceding twelve months. ${ }^{42}$

SEAQ is a screen-based system. Directly after Big Bang, the stock exchange gave its members the option of trading from screens on the exchange floor or from computer screens in their individual offices. Within a few months, the vast majority of members had abandoned the floor in order to trade from their own offices. In March 1987, the LSE became the world's first major stock exchange to close down its floor for the trading of bonds and equities. ${ }^{43}$ Market makers key-punch their quotations into the SEAQ system, and information vendors distribute the quotations to brokers, dealers, and investors who subscribe to the system. Once a subscriber receives the quotations on a screen in its office, it can execute its orders automatically at the best bid or offer by entering them into the LSE's SEAQ Auto Execution Facility ("SAEF") or into similar systems operated by two brokerage houses. Large orders (those in excess of ten percent of the security's normal market size) cannot be executed through SAEF but must be negotiated over the telephone. ${ }^{44}$

Because SEAQ is a system of competing market makers, it has no central facility to which all customers' orders must be routed. Instead, a customer is assured that his or her broker will execute his or her order at the best

41. For a discussion of the difference between a quote-driven system and an order-driven system, see Part V(A) of this article.

42. Poser, International Securities Regulation at 43-47 and 10 (Supp 1991) (cited in note 18).

43. Trading in listed options continued on the LSE floor until 1991. Id.

44. International Stock Exchange, Quality of Markets Quarterly Review at 8 (cited in note 12). 
available price by the common-law rule that an agent owes its principal the duty of acting with the utmost good faith, loyalty, and diligence. ${ }^{45}$ This duty is reinforced by the best-execution rule of the Securities and Investments Board ("SIB"), the U.K. regulatory authority functionally similar to the Securities and Exchange Commission ("SEC") in the United States. ${ }^{46}$ Furthermore, "agency crosses" (transactions where a broker acts as agent for both sides) must be disclosed to the market makers to enable them to make a better bid or offer for them. ${ }^{47}$

It can be argued, in my opinion persuasively, that efficient operation of the trading system depends on the ready availability of market information to all participants. SEAQ market makers' quotations, shown on subscribers' screens, enable them to determine which market maker is quoting the best bid, thus allowing best execution of their orders. Reports of completed transactions, which also are shown on subscribers' screens, provide brokers and investors with a current picture of total market activity. Nevertheless, in 1988 several market makers objected to the "transparency" of the market, on the grounds that immediate publication of large trades discourages market makers from executing these trades at competitive prices, allows "fair weather" traders (market makers who withdraw from the market in times of stress) to compete unfairly with market makers, and increases market volatility. ${ }^{48}$ As a result, the LSE adopted a rule change that reduced market transparency by permitting, with certain exceptions, large transactions (more than three times the security's normal market size) in active stocks not to be published until ninety minutes after their execution, and transactions in less active stocks not to be published until the next day. ${ }^{49}$

Although SEAQ is operated by one of the world's leading stock exchanges, it has many of the traditional characteristics of an over-the-counter market. First, most transactions are channeled through a market maker, making it unfeasible for routinely handled orders of buyers and sellers to be executed at a price between the best bid and the best offer. Nevertheless, this is not generally true for large orders: in the second quarter of 1991, seventy-five percent of all transactions of more than $£ 100,000$ in U.K. equities were negotiated at a price inside the "touch" (between the best bid and the best offer published by market makers). ${ }^{50}$ Second, because SEAQ does not concentrate all buy and sell orders in one place, market prices of securities are not determined by an auction-type method, but rather by the competing bids and offers of market makers.

45. See Floyd R. Mechem, $2 A$ Treatise on the Law of Agency $\$ 2411$, at 1974-76 (Callaghan, 2d ed 1914).

46. Core Rule 22, The Core Conduct of Business Rules, SIB Rulebook Amendments and Additions Release 94 (1991).

47. Richard Waters, New rules on UK trading under attack, Fin Times 19 col 3 (Jan 14, 1991).

48. International Stock Exchange, Review of the Central Market in UK Equities, Report of the Special Committee on Market Development 13 (March 1990) ("Elwes Report"); Poser, International Securities Regulation at 49-51 (cited in note 18).

49. International Stock Exchange, Quality of Markets Quarterly Review at 8 (cited in note 12).

50. London Stock Exchange, Stock Exchange Quarterly at 19 (cited in note 10). 
The low or non-existent profitability of many LSE market makers after the decline of trading activity following the 1987 market crash, and the consequent withdrawal of several of these firms from market making, ${ }^{51}$ should not obscure the fact that SEAQ has been highly successful in its principal goal of cutting the transaction costs of institutional investors and attracting foreign institutional investors to the London market. It is unlikely that the LSE could have enjoyed this success if it had not used the tools of automation in order to make its trading system more efficient.

\section{B. CAC: The Order-Driven System of the Paris Bourse}

The French securities market has undergone a process of deregulation similar to that of the United Kingdom. In 1989, the same year it abolished fixed commission rates, France abolished its system of government-licensed individual stockbrokers (agents), who were permitted to act only as brokers for customers and not as dealers for their own accounts, and replaced it with a system of member firms (sociétés de Bourse), which could engage in a broad range of activities including brokerage, trading, investment banking, and giving investment advice. Banks were permitted to own member firms of the Bourse, but not to become member firms themselves. By late 1991, only three of the fifty-seven member firms remained independent entities, while the remainder were controlled by domestic banks, foreign banks, or investment firms. ${ }^{52}$

The Paris Bourse took a more gradual approach than the LSE to the automation of its trading system. Instead of a Big Bang, which switched the trading of all equities and bonds to a computer-assisted system on a single day, the transformation of the Bourse has been accomplished over a period of more than five years. In 1986, the Bourse inaugurated its Cotation Assiste en Continue ("CAC") trading system for thirty of its most active stocks. By 1991, most listed stocks were traded through the CAC system. Government bonds, options, and futures, however, continued to be traded by open outcry on the floor of the exchange. ${ }^{53}$

Although CAC resembles SEAQ in that it is a screen-based system, it differs from the London system in that it is order-driven. ${ }^{54}$ CAC is an adaptation of the "CATS" system developed by the Toronto Stock Exchange. ${ }^{55}$ Using desk-top screens and keyboards in their offices, member firms send buy and sell orders for their own accounts and for their customers' accounts to the exchange's central computer, where the orders are

51. Poser, International Securities Regulation at 72-75 and 20-21 (Supp 1991) (cited in note 18).

52. Interview with Marc Outin, Head of Information, Marketing Division, Société des Bourses Françaises, Paris (Nov 29, 1991) ("Outin Interview"); see also Commission des Opérations de Bourse, 1990 Annual Report 44.

53. Poser, International Securities Regulation, at 384 and 94-95 (Supp 1991) (cited in note 18).

54. For a discussion on the difference between an order-driven system and a quote-driven system, see Part V(A) of this article.

55. "CATS" stands for Computer-Assisted Trading System. See Bernard Simon, Toronto recommends automated trading, Fin Times 16 col 4 (Jan 4, 1992). 
automatically ranked by price limit. Within each price limit, orders are queued in order of arrival. For example, an order to buy 100 shares of a stock at a price of ten would be ranked ahead of all buy orders at a lower price, but behind all previously received orders at a price of ten. ${ }^{56}$

The Bourse provides a pre-opening session from 9:00 a.m. to 10:00 a.m., when member firms feed their orders into the system. During this time, no transactions take place. At the opening of the market at 10:00 a.m., the central computer automatically calculates the opening price, which is the price at which the largest number of bids and offers in the system can be matched. Following the opening, trading is conducted on a continuous basis, and each new order that arrives in the system is automatically matched with an order or orders. Orders that cannot be matched are placed in a centralized "book," which CAC makes available for inspection by member firms on their screens. Thus, a member firm can see the size and limit price of each order, and the identity of the firm that placed it. A member firm may elect not to disclose a portion of an order that is placed on the book, but the undisclosed portion loses its time priority over disclosed orders at the same price that are subsequently entered into the system. The loss of priority rule provides an incentive to a firm to permit all of its orders to be disclosed to the market. Also, member firms and other subscribers to the system can see on their screens the details of executed transactions on a real-time basis, including the identity of the member firms that executed them.

Member firms are permitted to trade as principals with their own customers, or to execute both sides of a transaction for two customers, but all transactions are required to be put through the CAC system. All such crossed orders must be executed within the current market spread, except that a block transaction ${ }^{57}$ may be executed outside the spread if the member firm first fills any sell order with a limit lower, or any buy order with a limit higher than the proposed "cross." For example, if a broker wishes to execute a cross of 50,000 shares at a price of ten but cannot execute it because an order to sell 1000 shares at $9 \frac{1}{2}$ is on the book, the broker must first enter an order for his own account to buy the 1000 shares at $91 / 2$, thus clearing the way for the cross to be executed. 58

The Bourse's automated clearing and settlement system is tied into CAC. This system, called "Relit," was inaugurated in 1990 with eleven securities, and is expected to be fully operational by 1992. CAC's trade-reporting system generates the information necessary for clearing and settlement, and thus eliminates the necessity for member firms to exchange trade confirmations. Relit uses a continuous settlement system of five days, which it expects eventually to reduce to three days. ${ }^{59}$

56. Société des Bourses Françaises, The Paris Bourse: Organization and Procedures $11-12$ (1991).

57. The Stock Exchange Council (Conseil des Bourses de Valeurs) determines which stocks are approved for this block trading procedure and the number of shares that constitutes a block. Id.

58. Outin Interview (cited in note 52); Société des Bourses Françaises, The Paris Bourse at 11-14 (cited in note 56 ).

59. Société des Bourse Françaises, The Paris Bourse at 15-16 (cited in note 56). 
In summary, the CAC trading system has the following two key characteristics: (1) all orders to buy and sell securities are routed to a central facility, where they are executed at the best available price; and (2) market participants receive immediate disclosure of detailed information concerning orders in the system and actual transactions. Although both CAC and SEAQ are computer-assisted trading systems, SEAQ is different from CAC in that it neither has a central facility for the display of investors' orders, nor does it require immediate publication of all completed transactions. These differences must be kept in mind to understand the difficulties that have been encountered in reaching agreement on the EC's proposed Investment Services Directive.

\section{IV}

\section{The Specialist Trading System of the New York Stock Exchange}

In developing their new systems for trading securities, the managements of the LSE and the Paris Bourse were very much aware of-even though they did not emulate - the trading system used on the NYSE. ${ }^{60}$ Furthermore, both have regarded the specialist system as a possible solution to the problem of the inadequate liquidity of the trading markets for inactive issues. It is therefore relevant to this discussion to include a brief examination of the NYSE system.

As indicated above, neither the NYSE nor the other U.S. stock exchanges ${ }^{61}$ substantially altered their trading systems when they were deregulated in 1975. The NYSE trading system is essentially an order-driven system in two senses: (1) investors' orders are routed to a central location, the exchange's trading floor, where they are executed at the best available price by means of a "two-way auction" in which orders on each side of the market compete with each other for execution; and (2) it is possible for the orders of a buying customer and a selling customer, each represented by a broker, to meet without the intervention of a professional dealer. ${ }^{62}$

Nonetheless, the NYSE system also has some characteristics of a quotedriven system, in that a category of exchange member firms known as "specialists" are permitted, and in some situations required, to trade for their own account in order to offset temporary imbalances between supply and

60. In 1984, the LSE carefully examined the NYSE specialist system as a possible model before rejecting it in favor of a system based on NASDAQ. London Stock Exchange Report, The Choice of a New Dealing System for Equities 4-5 (July 17, 1984). The considerations entering into this decision are described in Poser, International Securities Regulation at 40-41 (cited in note 18).

61. The NYSE is by far the most important stock exchange in the United States, accounting for $85.49 \%$ of the total dollar volume of all trading activity in stocks, rights, and warrants on U.S. stock exchanges in 1989. Securities and Exchange Commission, 1990 Annual Report 146 (1991). Furthermore, much of the trading done on the other U.S. stock exchanges is in securities listed on the NYSE, at prices derived from the prices established on the NYSE. Norman S. Poser, Restructuring the Stock Markets: A Critical Look at the SEC's National Market System, 56 NYU L Rev 883, 892-93 (1981).

62. Poser, NYU L Rev at 888-89 (cited in note 61). 
demand.63 The specialist also acts as a broker, handling for other brokers limit-price orders that cannot be executed at the current market price. The specialist keeps a "book" of these orders, which is normally not disclosed to other members and which the specialist is prohibited from disclosing to other members selectively. ${ }^{64}$ Thus, the income of specialists is derived both from commissions for executing limit-price orders and from trading profits.

Although the NYSE had competing specialists at one time, there have been none since 1967.65 When a stock becomes newly listed on the NYSE, the exchange's management allocates it to a single specialist firm, which has the exclusive right to perform the functions of a specialist with respect to that security. The SEC and the exchange impose regulatory duties on specialists, specifically requiring "the maintenance, insofar as reasonably practicable, of a fair and orderly market" in the stocks in which they are registered. ${ }^{66}$ As a substitute for market maker competition, the specialist is supposed to offset temporary trading imbalances by buying and selling his specialty securities for his own account.

Specialists do not have total monopolistic control over the security, however. A certain amount of competition exists between the NYSE specialist and the specialists on one or more regional stock exchanges to which a particular security may be admitted to trading. There is also competition between specialists and the so-called "third market" (non-member dealers that make markets in listed stocks). ${ }^{67}$

In the Securities Acts Amendments of $1975,{ }^{68}$ Congress directed the SEC to facilitate the development of a national market system, to be achieved by the "linking of all markets for qualified securities through communication and data processing facilities." 69 Although the legislation did not define the national market system, Congress stated that it had "two paramount objectives": (1) "the maintenance of stable and orderly markets with maximum capacity for absorbing trading imbalances without undue price movements"; and (2) the "centralization of all buying and selling interest so that each investor will have the opportunity for the best execution of his order, regardless of where in the system it originates."70

During the 1970s, the SEC encouraged the NYSE and other U.S. stock exchanges to implement the national market system by utilizing two innovations that, if adopted, would have transformed the trading markets into (1) a system that would automatically route orders directly from brokers' offices to the specialist or market maker publishing the best bid or offer, called

63. [1990] 2 NYSE Guide (CCH) I 2104 (Rule 104.10(2), (3)).

64. Securities Exchange Act of 1934, § 11(b), 15 USC \& 78k(b) (1988).

65. Poser, 56 NYU L Rev at 953 (cited in note 61).

66. NYSE Rule 104.

67. Poser, 56 NYU L Rev at 888-95 (cited in note 61 ).

68. Pub L No 94-29, 89 Stat 97 (1976 \& Supp IV 1980), amending Securities Exchange Act of

1934,15 USC $\$ \$ 78-78 \mathrm{kk}$.

69. Securities Exchange Act of 1934, $\$ 11 \mathrm{~A}(\mathrm{a})(1)(\mathrm{D}), 15$ USC $\S 78 \mathrm{k}-1$ (a)(1)(D).

70. Securities Acts Amendments of 1975, S Rep No 94-75, 94th Cong, 1 st Sess 7 (1975). 
a common message switch ("CMS"), and (2) an electronic depositary for customers' limit-price orders throughout the national market system, called a consolidated limit order book ("CLOB"). The NYSE opposed both of these proposals: CMS because it would enable customers' orders to bypass the NYSE trading floor and its specialists, and CLOB because it had the potential of developing into a "black box" (creating a fully automated trading system that would have deprived specialist firms of their function of holding and executing limit-price orders, and consequently depriving them of a large portion of their incomes).

As envisioned, CLOB would have automatically executed customers' limitprice orders routed to it, on the basis of priority of price and time (orders at a more favorable price would have priority over those at a less favorable price, and orders at the same price would be executed in the order in which they were entered into CLOB). ${ }^{71}$ If CLOB had been implemented, it could have provided a computerized system for matching customers' orders, similar to the Paris Bourse's CAC trading system.

In order to foreclose the creation of a fully automated market and still meet the "best execution" goal that Congress had set for the national market system, the NYSE established, as a substitute for CLOB, a communications system linking the floors of the various U.S. stock exchanges that traded the same stocks. This system, known as the intermarket trading system ("ITS"), was approved by the SEC, which then dropped its CLOB and CMS proposals. ITS enables a broker or specialist on the floor of one exchange to transmit orders to another exchange displaying a better quotation (that is, higher bid or lower offer) than that displayed at the originating exchange. ${ }^{72}$ ITS has not, however, been a major factor in the trading markets. In 1990, only about six percent of NYSE share volume was done through ITS. ${ }^{73}$

The NYSE has automated certain of its trading-market procedures, if only to be able to handle its enormous daily trading volume. A system called "SuperDot" electronically routes customers' orders of 2000 shares or less to the specialist "post" on the exchange trading floor, where the orders are automatically executed or, in the case of limit-price orders, filed in the specialist's book. ${ }^{74}$ Nevertheless, the essential nature of the NYSE trading system has not changed during recent decades.

The NYSE has paid a price for its resistance to automating its trading market. (Investors too have paid a price-in the form of higher transaction costs. ${ }^{75}$ ) Recent years have seen the creation and growth of several automated trading systems, which compete with the NYSE for customers' orders. These include two systems for the crossing of institutional-size

71. Poser, 56 NYU L Rev at 922-31 (cited in note 61).

72. Id at 923-24.

73. NYSE Fact Book 1991 at 12, 24.

74. Id at 21 .

75. On the other hand, a recent study has concluded that some trades are done away from the NYSE at prices slightly less favorable to customers. Floyd Norris, Investors Hurt When Trades Shift, NY Times Di col 6 (Mar 2, 1992). 
orders, operated by Instinet and Jefferies \& Co., and an automated execution system for listed stocks, operated by Bernard Madoff \& Co. ${ }^{76}$ These three firms, which are registered broker-dealers but are not member firms of the NYSE (as described below, NYSE Rule 390 prevents member firms from engaging in these activities), enable brokers to execute orders at a substantially lower cost than on the NYSE, in part owing to the use of computerized trading systems. It has been reported, for example, that over one hundred NYSE member firms, including several of the largest discount brokers, execute off-exchange orders with Madoff for their customers in NYSE-listed securities. ${ }^{77}$ NYSE Rule 390 permits a NYSE member firm to execute customers' orders off the exchange with another person, if the member firm is not also acting as agent for such other person. ${ }^{78}$

An increasing volume of trading in U.S. equities is executed abroad, in part as a result of the efforts of NYSE member firms to avoid the strictures of Rule 390, which severely limits trading by NYSE member firms off the exchange in most listed securities. The rule prohibits member firms from trading as principal, making markets, and executing both sides of customers' transactions off the exchange, but the rule does not apply to transactions on other stock exchanges, including foreign stock exchanges. ${ }^{79}$ Trading in NYSE-listed stocks in London and, to a lesser extent, in other European financial centers is also done for purposes other than to avoid Rule 390: to minimize transaction costs and to avoid the more rigorous transaction reporting requirements applicable in the U.S. securities markets. ${ }^{80}$

In the first quarter of 1991, the NYSE's average daily volume of 194 million shares represented only about seventy-five percent of the total trading volume in NYSE-listed stocks. The five most important regional U.S. stock exchanges had a combined average daily volume in these issues of twentyeight million shares. Overseas markets traded an estimated twenty million shares; while Madoff handled nine million shares, Instinet eight million shares, and Jefferies three million shares. ${ }^{81}$ Thus, although the NYSE clearly remains the primary market for its listed stocks, a substantial proportion of the volume in these issues is being executed away from the primary market, in part as a result of the greater cost-efficiency of automated trading systems.

\section{V}

\section{Questions Presented by the Movement Toward Automated Trading Systems}

The three principal issues that regulators, stock exchanges, and market participants in the EC member states will need to resolve in determining the

\footnotetext{
76. Heyman, Computerized Trading Systems at 7-8 (cited in note 37).

77. Richard L. Stern, Living off the spread, Forbes 66 (July 10, 1989).

78. [1990] 2 NYSE Guide (CCH) If 2390 (Rule 390(b)).

79. Id at ๆ9 3651-52 (Rule 390).

80. Heyman, Computerized Trading Systems at 11-12 n25 (cited in note 37).

81. Id at $9-10$.
} 
shape of the securities markets of the future are: (1) the choice between a quote-driven and an order-driven market; (2) the amount of "transparency" that is appropriate; and (3) whether the markets should be separated between active and inactive stocks, or between institutional and retail investors, or both.

It should not be assumed, of course, that a single trading system will eventually be used by all of the major European stock exchanges; it is quite possible that different systems in different countries will coexist for a considerable period of time. Nevertheless, in the "single market" (of post1992 Europe) discussed by Waide Warner in his article, ${ }^{82}$ in which multiple listing of securities will be substantially facilitated, it is more likely that trading in stocks of international interest will gravitate to the market that provides the most liquidity and efficiency. Experience shows that, once a particular market has become the primary market for a security, that market tends to exert a strong pull on the overall trading of that security. ${ }^{83}$ Furthermore, it is possible, although perhaps not likely, that the provisions of the proposed ISD will have the unfortunate result of cutting off further experimentation and forcing all the European markets into a single mold.

It is not possible at this time to provide a definite answer to the question of how the European securities markets should be structured. The answer will most likely evolve over a period of time as a result of experience gained. Nonetheless, the experience that has already been gained with automated markets may point the way to some tentative answers.

\section{A. A Quote-Driven or an Order-Driven Market?}

In theory, an order-driven market should impose lower transaction costs on investors than a quote-driven market, because the former enables investors' orders to be executed without the intervention of a professional dealer. By buying from investors at the bid price and selling to investors at the offer price, the dealer (or market maker) in a quote-driven system extracts compensation from the trading system in the form of the "spread" between the bid and offer. For example, in an order-driven market, one customer might buy a security directly from another customer at a price of fifty, whereas in a quote-driven market the selling customer might receive a price of fortynine from a professional dealer, who would then sell the security to the buying customer at a price of fifty-one. Furthermore, an order-driven market ideally concentrates all customers' orders at one location, providing the best opportunity for the highest bid throughout the system to meet the lowest offer.

The principal drawback of an order-driven trading system is that a customer's order entered into the system may not immediately encounter another customer's order on the other side of the transaction at the same

82. Warner, "Mutual Recognition", 55 L \& Contemp Probs 7 (cited in note 1).

83. Poser, 56 NYU L Rev at 954 (cited in note 61 ). 
price (or at "the market"). Thus, an order-driven trading system may lack "liquidity," the characteristic of a security that enables an investor to execute a transaction in the security promptly, at a price reasonably related to its current market price. ${ }^{84}$ A quote-driven system seeks to remedy this defect by the presence of market makers, who continuously advertise the market by quoting "firm" (guaranteed) prices to buy and sell securities. As a general proposition, the higher the bids and the lower the offers quoted by market makers, the more customers will be induced to enter their orders into the system.

Ideally, a quote-driven system attempts to give investors the best price through the competition among market makers, rather than through the concentration of all buy and sell orders in the same place. In practice, institutional users prefer a quote-driven system that allows them to negotiate with a market maker in order to obtain a better price, rather than dealing at the price quoted on the screen. ${ }^{85}$ This practice has limited the usefulness of the market information (that is, the bid and asked quotations) provided by the system. One commentator observed that: "Only in order-driven markets, where buyers and sellers enter their orders and matching takes place centrally, would people be likely to deal on screen." 86 For that reason, it is possible that the LSE will eventually change to an order-driven system, although its management has continued to insist that it is committed to its quote-driven system, at least for the trading of U.K. securities. ${ }^{87}$

The actual experience of SEAQ and CAC during their first years of operation throws an interesting light on the relative virtues of the two types of trading systems. Both systems have provided adequate, and at times even sensational, liquidity for their actively traded, large-capitalization stocks, but both have encountered severe problems in maintaining liquid markets for the less active issues, usually those of smaller companies. Paradoxically, the LSE and the Paris Bourse have each considered adopting a version of the other's trading system to provide more liquidity for less active stocks. For several years, the LSE has toyed with the idea of introducing an electronic orderdriven trading system for less active stocks, which would operate parallel to SEAQ. ${ }^{88}$ In France, the Société des Bourses Françaises, the self-regulatory body that runs the stock exchanges, has proposed the adoption of a kind of

84. See John Downes \& Jordan E. Goodman, Dictionary of Finance and Investment Terms 213 (Barron's, 1991).

85. "In a quote-driven system, spreads are often a starting point for negotiation." Last Orders?, The Economist at 91 (cited in note 40).

86. Richard Waters, Reuters makes topical move in electronic share price market, Fin Times $8 \mathrm{col} 6$ (Oct 14, 1991).

87. See, for example, Elwes Report at 7 (cited in note 48).

88. International Stock Exchange, Quality of Markets Quarterly Review at 16 (cited in note 12); Elwes Report at 11 (cited in note 48). 
specialist system for these issues, in which sole market makers would publish quotations to buy and sell particular securities. ${ }^{89}$

It appears reasonable to conclude that the characteristics of a particular stock might have a greater impact on its liquidity than does the trading system. Professional dealers are understandably reluctant to commit their capital to the risky business of making markets in inactive issues, and the markets that they do make are likely to have very wide spreads. The liquidity that a dealer system can provide in these issues is therefore limited. Conversely, the markets for active issues are likely to be reasonably liquid, whether or not there are dealers publishing quotations. Without denying the contribution that professional dealers may make to the markets, it is hard to avoid the conclusion that they are most interested in offering their services where these services are not only most profitable to themselves, but also least needed by investors.

\section{B. How Much "Transparency" Is Appropriate?}

In market terms, "transparency" means the extent to which data on prices and transactions are made available to market participants. ${ }^{90}$ It refers to information about the following: (1) bid and asked orders and quotations, including limit-price orders above and below the current market; (2) real-time (immediately after the transaction occurs) prices and volume of actual transactions; and (3) the identity of the sources of orders and transactions. ${ }^{91}$

Transparency is important for both the fairness and the efficiency of securities markets. Seventy years ago, a Wharton School professor of finance stated this proposition with admirable clarity:

Owing to the elaborate quotation service of our organized markets, owners of nearly

all listed securities are enabled to know the price from day to day. In the absence of

89. Outin Interview (cited in note 52). In October 1992, the LSE announced that its less liquid stocks would be traded through a single-market maker system, resembling the specialist system of the NYSE. Richard Waters, Seats for change on the Exchange, Fin Times 27 (Oct 15, 1992).

90. Julian R. Franks \& Stephen M. Schaefer, Equity Market Transparency, London Stock Exchange Quarterly 7 (April-June 1991).

91. The International Organization of Securities Commissions ("IOSCO") has listed the following types of information that can be provided:

1. the price of the most recent transaction;

2. the quantity of the most recent transaction;

3. the time of the most recent transaction;

4. the parties to the most recent transaction;

5. the best current bid and asked prices;

6. the quantity available at those prices;

7. the parties who placed those orders;

8. the bid and asked prices behind the best;

9. the quantity available at those prices;

10. the parties who placed those orders;

11. any requests for quotes in the system;

12. the parties who placed those requests for quotes;

13. the number of individuals currently logged into a particular market; and

14. the identity of those individuals.

IOSCO, Screen-based Trading Systems for Derivative Products, IOSCO Report of the Technical Committee 14 (June 1990). 
exchange markets, transactions would be private and prices would certainly not be representative of the general judgment. Even if recorded, prices determined in private offices might easily be designed to mislead. On our exchanges, however, all transactions are made in the open market, under proper regulations, and quotations are immediately spread broadcast, first by the ticker and news services and immediately thereafter by the daily press. ${ }^{92}$

The transparency of a market attracts investors. The electric stock ticker, introduced by the NYSE in 1867, broadened public interest in that market and played an important role in the development of the U.S. stock market. ${ }^{93}$ Similarly, the U.S. over-the-counter market has had an explosive history of growth since the 1970s, when the National Association of Securities Dealers ("NASD") made inter-dealer quotations publicly available, followed by the publication of prices and volume of completed transactions by newspapers. ${ }^{94}$

Nevertheless, the influence of the disclosure of market information, at least on institutional investors, is subject to doubt. For example, SEAQ International, an informally organized screen-based trading system that is maintained by the LSE for the shares of large-capitalization companies of international interest (companies whose shares are traded actively in foreign countries) has grown rapidly during the past few years, despite the absence of any publication (either immediate or delayed) of price or volume on individual trades. An explanation for this may be that SEAQ investors are exclusively professionals who have the means, not available to small investors, to obtain this information. ${ }^{95}$

Despite the apparent advantages of transparency, the question of how much transparency is appropriate has been a principal source of dispute in the negotiations concerning the proposed ISD. As stated above, the London Stock Exchange currently permits a delay of ninety minutes between the execution of large transactions in the SEAQ system and the publication of information concerning the transactions. According to a report sponsored by the exchange, "[a] major concern of market makers is that immediate publication may expose their positions to competitors who may then engage in 'spoiling', that is, competitors changing their prices on the screen to make it difficult for a market maker who has just taken on a large position to dispose of it profitably."'96

The CAC trading system used on the Paris Bourse, on the other hand, discloses considerable information on quotations and prices. All CAC subscribers can see the entire "book" of limit-price orders above and below the current market price of a stock, the price and volume of completed trades, and the identity of the buyers and sellers. Subscribers that are member firms

92. Solomon Stephen Huebner, The Stock Market 23-24 (Appleton, 1922).

93. Frank G. Zarb \& Gabriel T. Kerekes, The Stock Market Handbook 74 (Dow Jones-Irwin, 1970).

94. Michael J. Simon \& Robert L.D. Colby, The National Market System for Over-the-Counter Stocks, 55 Geo Wash L Rev 17, 23-24 (1986). The annual volume on NASDAQ increased five-fold between 1980 and 1990, while share volume on the NYSE increased by "only" three and one-half times during the same period. NASDAQ Fact Book 6 (1991); NYSE Fact Book 77 (1991).

95. Franks \& Schaefer, London Stock Exchange Quarterly at 11 (cited in note 90). See note 4.

96. Franks \& Schaefer, London Stock Exchange Quarterly at 10-11 (cited in note 90). 
are also shown the identity of the bidders and offerors whose orders are placed in the book. ${ }^{97}$ Realistically, however, the transparency of the CAC system is limited by the fact that the banks, through which most investors do their trading, have been unwilling to give their clients access to disclosures by subscribing to the system on behalf of their clients, preferring instead to sell mutual funds to their clients. Not surprisingly, the French negotiators in Brussels took the position that the ISD should require immediate publication of all transactions, whereas the British favored delayed reporting of large transactions. ${ }^{98}$

The U.S. markets are thought to be very transparent because quotations and price-and-volume information are immediately available. Nevertheless, the specialist's book of limit-price orders is normally kept secret from everyone besides the specialist. While this secrecy gives the specialist a unique-and perhaps unfair-advantage over other traders, it may be essential to induce specialists to risk their own capital in order to perform the function of adding to the fairness and orderliness of the markets for listed stocks. Notwithstanding this situation, member firms of the Paris Bourse recently rejected a proposal to adopt a form of the specialist system for less active stocks because they did not believe that they could operate successfully as specialists, given the transparency provided to professionals and investors by the CAC system. ${ }^{99}$

Perhaps the only conclusion that can be drawn is that, while transparency is undoubtedly an important benefit to investors, and is to be expected in a "pure" order-driven market, transparency must be somewhat limited if a strong dealer system capable of handling institutional-size transactions is desired. If total transparency is insisted upon in a quote-driven market, it may be that dealers will either widen their quotations, reducing market liquidity, or they will simply evade the disclosure requirements, for example, by informally guaranteeing an investor a minimum price and then delaying publication of the trade until the dealer can match the order with an order from another investor. ${ }^{100}$

\section{Should There Be Separate Trading Markets?}

1. Active and Inactive Stocks? Despite the differences between the British and French screen-based trading systems, they are similar in one important respect: both markets are able to provide reasonably liquid markets for active issues, but not for inactive issues. In 1990, the LSE reported that the "touch" between the best bid and the best offer for "alpha" (the most active) stocks was 1.61 percent of the market price, whereas the touch for "gamma" (inactive) stocks was a highly unsatisfactory 10.24 percent. ${ }^{101}$ While I have

97. Outin Interview (cited in note 52).

98. Andrew Hill, Securities directive stalled by divisions, Fin Times 2 col 1 (Dec 17, 1991).

99. Outin Interview (cited in note 52).

100. Franks \& Schaefer, London Stock Exchange Quarterly at 9-10 (cited in note 90)

101. International Stock Exchange, Quality of Markets Quarterly Review at 10-13 (cited in note 12). 
not seen comparable statistics from the Paris Bourse, an on-line demonstration of the CAC system in late 1991 revealed-albeit anecdotallya similar situation: there appeared to be liquid markets in the most active stocks, while, for the less active stocks, the book was extremely sparse, and touches were wide. ${ }^{102}$

The managements of the two exchanges have separately proposed correcting this problem by creating a special market for less-active stocks. In the United Kingdom, the LSE's Elwes Committee in March 1990 proposed establishing an electronic matching system for these stocks, to be known as "CLOSE" (Central Limit Order Service). ${ }^{103}$ SEAQ market makers opposed this proposal, however, apparently because it would deprive them of part of their order flow on which they depend for their profits. ${ }^{104}$ Later that year, the exchange's governing body tabled the proposal. In 1991, the LSE proposed a new system that would include all but the 500 most active of its listed stocks. The remaining 1700 stocks would be traded by means of a "sole trader" system, which bears a strong resemblance to the U.S. specialist system. All orders would be routed to an exchange member designated as the sole trader for that stock, who would match buy and sell orders where possible, and would have the exclusive right to participate as a dealer. ${ }^{105}$ As stated above, the Paris Bourse has also considered establishing a type of specialist system for inactive stocks.

In theory, there is nothing wrong with having different trading systems for securities with different characteristics. ${ }^{106}$ Separating the markets in this way would not be unfair, so long as each segment of the market lives up to the warranted expectations of investors. ${ }^{107}$ In the United States, the order-driven stock exchange markets and the quote-driven over-the-counter market have existed side by side for many decades. The differences between these two markets have been defended by the justification that, in general, the securities traded in each have different characteristics: NYSE-listed stocks being usually more active and better known than those traded over the counter. ${ }^{108}$

102. Outin Interview (cited in note 52).

103. Elwes Report at 11 (cited in note 48).

104. See Poser, International Securities Regulation at 7-8 (1991 Supp) (cited in note 18).

105. Id. See note 88. The LSE has also established an electronic "bulletin board" on which investors can display their buy and sell orders for less active stocks. Waters, Fin Times at 27 (cited in note 89).

106. The decision as to which securities would be traded in which market could be made by the companies themselves, by the operators of the markets (the stock exchanges or over-the-counter associations), by the government, or by some combination of the three. In the United States, for example, each stock exchange has listing standards, relating, among other things, to size, profitability, number of shareholders, and number of shares available for trading. These listing standards are rules of the particular exchange and must be approved by the SEC. Nevertheless, the decision whether to list on a particular exchange is made by the company. Thus, a company may first be traded in the over-the-counter market, then list its common stock on the American Stock Exchange (Amex) when the company and its stock meet the Amex's listing standards, and later transfer to the NYSE when the company and its stock meet the NYSE's higher listing standards.

107. 2 Report of the Special Study of Securities Markets of the Securities and Exchange Commission, H Doc No 95, Pt 2, 88th Cong, 1st Sess 834-36 (1963).

108. Id. 
It is unlikely, however, that any particular trading system will succeed in providing substantially greater liquidity for inactive stocks. ${ }^{109}$ Professional dealers are generally unwilling to make close markets in these issues. As the experience of SEAQ shows, competing market makers have not done so, even though they also enjoy the right to make markets in the more profitable active stocks. Nor is it likely that a specialist-like sole-trader system would do any better, particularly if the sole traders were confined to dealing in inactive issues. In fact, it has been shown that the NYSE specialist, who has an exclusive franchise to make markets in a variety of active and inactive stocks, tends to issue wide quotes, or to avoid participating altogether in inactive stocks. ${ }^{110}$

An order-driven matching system may be the more appropriate trading system for inactive stocks, assuming that investors are made aware that they can expect only limited liquidity in these issues. The opposition that SEAQ market makers have expressed toward such a system cannot help but create a suspicion that they derive substantial profits from the wide spreads in these issues rather than providing liquidity by narrowing the spreads, or possibly that they are concerned that an order-driven system would become the thin edge of the wedge to allow an auction process for all stocks. Furthermore, as a practical matter, there is little competition among market makers in these issues; about 150 of these stocks have only one market maker."11 A matching system would eliminate the dealers' profits, probably without adversely affecting liquidity.

2. Institutional and Retail Investors? Occasionally, securities market regulators place the desirability of separating the securities markets into institutional and retail markets on the reform agenda. ${ }^{112}$ This question is sometimes confused with the question discussed above-whether there should be separate markets for active and for inactive stocks. Perhaps this is because institutional investors tend to concentrate their trading in largecapitalization, active stocks that have markets with sufficient liquidity to absorb purchases and sales of institution-size blocks of shares. London's SEAQ International market, for example, is dominated by institutional investors who concentrate their trading in the stocks of approximately 650 major companies of worldwide interest. ${ }^{113}$

109. See Poser, International Securities Regulation at 7-10 (1991 Supp) (cited in note 18); Richard Waters, Survival of the biggest, Fin Times $17 \mathrm{col} 1$ (Dec 11, 1991).

110. Poser, International Securities Regulation at 86-87 (cited in note 18).

111. Id at 10 (Supp 1991).

112. In November 1991, two major questions faced the French exchanges: (1) whether they should separate the "wholesale" market from the "retail" market and (2) whether an order-driven or a quote-driven market would be preferable. Outin Interview (cited in note 52).

113. Poser, International Securities Regulation at 24 (Supp 1991) (cited in note 18). Another example of a virtually exclusively institutional market is that created by SEC Rule 144A, which permits qualified institutions to trade unregistered securities among themselves. 17 CFR $\S 230.144 \mathrm{~A}(1990)$. 
It does not necessarily follow, however, that the shares of smaller, newer, and lesser-known companies are more appropriate investments for individual investors than are those of large companies. For risk-averse individuals, the latter may be more suitable. Institutions and individuals are often likely to invest in the same types of securities.

In one sense, there is already a de facto separation between the retail and wholesale markets. This separation is caused by the institutionalization of the markets during recent decades, a result of the increasing tendency of individual investors to invest in the market indirectly through the medium of financial institutions, such as mutual funds and pension funds. In this two-tier market, individuals invest by acquiring an interest in an institutional investor. Direct participation in the trading market is left to the institution.

Nevertheless, the process of institutionalization is far from complete, and individual investors still remain a significant factor in the markets. In the United Kingdom in 1990, for example, individual investors accounted for 18.1 percent of the value of all transactions, seventy-three percent of the number of transactions, and 44.7 percent of all commission revenue received by LSE member firms. ${ }^{114}$

One probable result of separating the markets by type of investor would be the eventual driving out of the remaining retail investors from the market. There are two reasons for this result: (1) a market with only the orders of individual investors would probably not have sufficient liquidity to remain viable; and (2) individual investors might lose confidence in the fairness of the markets if institutions were able to receive better executions of their orders than were individuals. To some extent, this has already happened on the LSE. Further, it is not likely that institutional investors would benefit from the separation of the market into its retail and wholesale components. Such a step would certainly deprive the market of a certain amount of its liquidity, to the detriment of institutional investors. Unlike individuals, who may have a variety of personal motives for buying or selling securities at a particular time, institutions often act in unison, buying or selling on the basis of similar analyses of the market. An empirical study of institutional trading conducted by the SEC in 1971 (long before the advent of computer-generated "program trading" further exacerbated the problem) found that institutions' net trading imbalances (the difference between institutional purchases and institutional sales), as a percentage of total institutional trading volume, were substantial. In a randomly selected group of NYSE listed stocks, these imbalances amounted to 55.4 percent. The SEC drew the following conclusion from the data:

The analysis of net institutional trading imbalances in terms of percentages is a measure of the extent to which institutions could not trade by themselves without interaction with smaller institutions[,] . . market makers or individual investors. Even in the larger NYSE stocks, where the percentage net imbalance is the smallest, institutions tend to buy two-thirds more than they sell in a particular month or vice

114. International Stock Exchange, Quality of Markets Quarterly Review at 26 (cited in note 12). 
versa. In the random NYSE stocks . . the percentage net imbalances are even greater. Existing institutional volume and patterns of trading could not be maintained if these surveyed institutions were segregated into a separate market and compelled to trade only with each other. ${ }^{15}$

\section{VI}

\section{Conclusion}

Although the securities markets of the member states of the EC have different trading systems, all of the major and several of the less important stock markets of Europe have committed themselves to the electronic trading of equities. The general acceptance of electronic trading is hardly surprising, in view of its potential to increase both fairness and efficiency.

Approval of the proposed Investment Services Directive has been delayed because of differing views as to how the European markets should be structured, although it appears that agreement has now been reached. One of the most important differences was between the order-driven trading system of the Paris Bourse and the quote-driven system of the London Stock Exchange. Each of these systems has advantages and limitations. Although there is reason to think that an order-driven system may be better adapted to electronic trading, the success of London's SEAQ market-maker system, particularly in the trading of large-capitalization foreign stocks, seems to point the other way. It is therefore not possible to reach a definite conclusion on the basis of the evidence that is available today. Furthermore, the wiser course would be to avoid forcing the trading systems of the European securities markets into a single mold, but rather to allow experimentation to continue in a competitive environment.

It is ironic that the U.S. markets for listed securities, which have a reputation as the most fair and efficient in the world, are among the few that still retain face-to-face trading by open outcry on a traditional trading floor. ${ }^{116}$ The advent of the automated trading systems raises a question as to how much longer the NYSE will be able to afford the high costs and inefficiencies of its own increasingly outmoded trading system. A substantial portion of the volume of activity in NYSE listed stocks is already being diverted to offexchange automated trading systems, both in the United States and abroad. It does not seem unreasonable to surmise that, once the European Community's Investment Services Directive takes effect, the competitive threat posed to the NYSE by economic and technological developments in Europe will become even greater. At some point, it may help spur the NYSE into adopting computerized trading.

115. 4 Institutional Investor Study Report of the Securities and Exchange Commission, H Doc No 92-64, Pt 4, 92d Cong, lst Sess 1405 (1971) (emphasis added).

116. The Tokyo Stock Exchange has a trading system similar to the CAC system but does not at present utilize it for all listed stocks. 
